Crop Breeding and Applied Biotechnology 13: 67-74, 2013

Brazilian Society of Plant Breeding. Printed in Brazil

\title{
ARTICLE
}

\section{Genetic variation in the emblematic Puya raimondii (Bromeliaceae) from Huascarán National Park, Peru}

\author{
Claudia Teresa Hornung-Leoni ${ }^{1}$, Victoria Sosa ${ }^{2}$, June Simpson ${ }^{3}$ and Katia Gil ${ }^{3}$
}

Received 30 July 2012

Accepted 15 January 2013

\begin{abstract}
Puya raimondii, the giant Peruvian and Bolivian terrestrial bromeliad, is an emblematic endemic Andean species well represented in Huascarán National Park in Peru. This park is the largest reserve of puna (high altitude plateau) vegetation. The objective of this study is to report on genetic variation in populations of P. raimondii from Huascarán and neighboring areas. AFLP profiles with four selective primer combinations were retrieved for 60 individuals from different zones. Genetic variability was estimated and a total of 172 bands were detected, of which 79.1\% were polymorphic loci. The results showed genetic differentiation among populations, and gene flow. A cluster analysis showed that individuals of $\mathrm{P}$. raimondii populations located in different mountain systems could be grouped together, suggesting long distance dispersal. Thus, conservation strategies for P. raimondii have to take into account exchange between populations located far apart in distance in order to preserve the genetic diversity of this showy species.
\end{abstract}

Key words: AFLP, populations, gene flow, bromeliads.

\section{INTRODUCTION}

Bromeliads represent an important group with high diversity in Neotropics, particularly in America (only one species growth in Africa) (Benzing 2000). Puya is a genus with special importance in the Andes, and Puya raimondii Harms, dubbed "Queen of the Puna" by Antonio Raimondi (1874), is the most prominent constituent of this habitat and an emblematic plant of the Andean flora. Plants of this giant terrestrial bromeliad grow solely in puna, a high altitude Andean ecosystem, in a few regions of Peru and Bolivia, at elevations of $4000-4500 \mathrm{~m}$ asl. It is the largest Bromeliaceae in the world, reaching heights up to $12 \mathrm{~m}$ (Hornung-Leoni and Sosa 2005). This species is monocarpic, producing a single gigantic inflorescence at the end of its life. Plants take from 40 to 100 years to flower (Benzing 2000, Hornung-Leoni and Sosa 2004). Only a few individuals within a given population will bloom in any year (Benzing 2000, Hornung-Leoni and Sosa 2004), but when they do, hundreds of thousands of seeds are produced (Raimondi 1874).
The species is listed as endangered by the IUCN since its low number of individuals in scattered populations it is considered as an endangered species with only a few populations worldwide (www.iucnredlist.org). Although Puya raimondii is considered endangered in Peru (Law No. 043-2006-AG), only the country's best-known Puya communities in Huascarán are protected. One of the main threats to these communities are fires, which are set to create pastureland, or the thorny leaves are burnt to facilitate access to the starch in the trunks for cattle fodder (Lambe 2008). Huascarán is the main national park in Peru, and Chanchayllo is not in a protected area. The first area is designated a Natural Heritage of Humanity and forms part of the UNESCO Biosphere reserves (http://whc.unesco.org/ en/list/333). Ecotourism in Huascarán, where a significant number of populations of this species are located, is mainly based on Puya raimondii. This plant is notorius by the giant size compared with local flora (personal obs.). The species is considered one of the most important in Peru: an emblematic plant of the Andean flora.

\footnotetext{
1 Centro de Investigaciones Biológicas, Herbario HGOM, Universidad Autónoma del Estado de Hidalgo, Apartado Postal 69-1, Plaza Juarez Centro, Pachuca, Hidalgo, Mexico.*E-mail: clauhl@gmail.com

2 Instituto de Ecología, A. C. Apartado Postal 63, 91070 Xalapa, Veracruz, Mexico

${ }^{3}$ Departamento de Ingeniería Genética, CINVESTAV, Unidad Irapuato, Apartado Postal 629, 36500 Irapuato, Guanajuato, Mexico
} 
There are previous genetic studies made in different genera of the family Bromeliaceae with allozymes, microsatellites, RFLP and AFLP markers (E.g. Murawski and Hamrick 1990, Rex et al. 2007). For Puya, the present study was only preceded by two interesting works with different biological units and hypotheses to investigate (Sgorbati et al. 2004, Schulte et al. 2010). Previous studies in P. raimondii determined the genetic structure of eight Puya raimondii populations in Huascarán-Peru and detected only 14 genotypes (Sgorbati et al. 2004). Only a few of the 217 AFLP marker loci screened were polymorphic and four populations were completely monomorphic, suggesting inbreeding.

The objective of this study is to determine genetic variation in populations of Puya raimondii in Huascarán National Park and neighboring areas (Canchayllo) in Peru using AFLP profiles. Individuals from two different mountains system were analized, in order to compare the genetic structure of populations in both areas, exploring AFLP markers with new primers. Both areas included in this study represent separated mountain systems ("Cordillera Blanca and Cordillera Negra"). In general, for plant populations, lack of genetic variation influences adaptation to habitats, rendering them even more vulnerable to anthropic pressure and climate change. It was hipotetized that, due to previous studies in Huascarán (Sgorbati et al. 2004), the genetic variation inside the national park will be low, and the values could be higher in neighboring areas.

\section{MATERIAL AND METHODS}

\section{Study area}

In this study, samples of both Huascarán and Canchayllo localities were included, which represent different mountain systems separated by a valley (putative barrier). Mountains from Huascarán Park conform part of the "Cordillera Blanca" in the central province of Ancash and ( $9^{\circ} 52^{\prime} 37^{\prime \prime}-9^{\circ} 53$ ' $27^{\prime \prime} \mathrm{S}, 77^{\circ} 15^{\prime} 26^{\prime \prime}-77^{\circ} 16^{\prime} 48^{\prime \prime} \mathrm{W}$; alt $4035-4600 \mathrm{~m}$ asl) and mountains from Canchayllo are in the "Cordillera Negra" (11 $49^{\prime} 48^{\prime \prime}-56.11^{\prime \prime} \mathrm{S}$ and $75^{\circ} 41^{\prime} 44^{\prime \prime}-42^{\prime} 55.25^{\prime \prime} \mathrm{W}$; alt 3600-4100 m asl) (Table 1). Mountains from Huascarán have higher elevations than Canchayllo. Although both localities are in different mountain systems they represent the puna from Peru, which is a dry habitat with a variable climate in a single day (high fluctuations of temperature occur in a day, reaching $25^{\circ} \mathrm{C}$ and in nights of intense cold, temperatures can drop below $0{ }^{\circ} \mathrm{C}$ ), at high elevations (alt 3600-4200 m asl) in South American Andes with predominantly herbaceous plants (Ribera 1992). The localities in Peru where $P$. raimondii were collected are shown in Figure 1.

\section{Genetic sampling}

Leaf tissue was collected at field and preserved in silica gel. Five populations with a total of 60 individuals of Puya raimondii were sampled in Huascarán Park and in Canchayllo, and including 7 to 14 individual per population (Table 1), considering the collect permission suggestions.

\section{DNA extraction and analysis}

Total genomic DNA was isolated from silica gel dried leaf tissue. Samples were then frozen in liquid nitrogen with mercaptoethanol and ground to a power. For the extraction, it was used a modified 2x CTAB method (Doyle and Doyle 1989). DNA was treated with RNase and incubated for 30 min to eliminate RNA in the samples. DNA concentration was adjusted to $200 \mathrm{ng}$ per $\mu \mathrm{L}$ for each sample.

Table 1. Genetic diversity in populations of $P$. raimondii

\begin{tabular}{|c|c|c|c|c|}
\hline Population/Individual & Locality & $\mathbf{P}$ & $\mathbf{P}(\%)$ & Ht \\
\hline $\mathrm{R} 1 / 7$ & N.P. Huascarán $\left(9^{\circ} 52^{\prime} 37.1^{\prime}\right.$ S, $\left.77^{\circ} 16^{\prime} 23.2^{\prime \prime} \mathrm{W}\right)$ & 96 & 55.81 & 0.178 \\
\hline $\mathrm{R} 2 / 14$ & N.P. Huascarán ( $9^{\circ} 53^{\prime} 00^{\prime}$ S, $77^{\circ} 15^{\prime} 26^{\prime}$ W) & 68 & 39.53 & 0.130 \\
\hline $\mathrm{R} 4 / 13$ & Canchayllo $\left(11^{\circ} 49^{\prime} 56.11^{\prime \prime} \mathrm{S}, 75^{\circ} 42^{\prime} 55.25^{\prime \prime} \mathrm{W}\right)$ & 87 & 50.58 & 0.172 \\
\hline $\mathrm{R} 5 / 10$ & 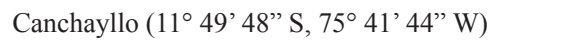 & 66 & 38.37 & 0.129 \\
\hline \multirow{4}{*}{ Total $(5 / 60)$} & & & $\mathrm{A}$ & $1.791 \pm 0.408$ \\
\hline & & & $\mathrm{H}_{\mathrm{s}}$ & $0.197 \pm 0.031$ \\
\hline & & & $\mathrm{G}_{\mathrm{st}}$ & 0.144 \\
\hline & & & $\mathrm{Nm}$ & 2.97 \\
\hline
\end{tabular}

Note: Samples from Peru in the Canchayllo localitity ("Cordillera Negra") were collected from 3600 to $4100 \mathrm{~m}\left(11^{\circ} 49\right.$ ' $48^{\prime \prime}-56.11^{\prime \prime} \mathrm{S}$ and $75^{\circ} 41^{\prime} 44^{\prime \prime}-42^{\prime} 55.25^{\prime \prime}$ W);

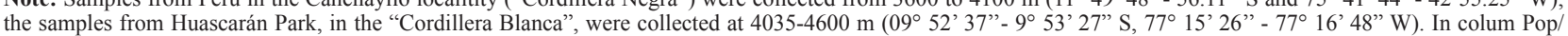
Indiv. the number of populations is shown (R1 until R5), and the number of individuals are showed after diagonal line. $\mathrm{P}=$ number of polymorphic loci between species and populations. $\mathrm{P} \%=$ percentage of polymorphisms. $\mathrm{H}=$ Nei's gene diversity for subdivided populations within species. $\mathrm{A}=$ mean number of alleles per locus, $\mathrm{H}=$ genetic diversity within populations. $\mathrm{G}_{\mathrm{st}}=$ Coefficient of gene differentiation. $\mathrm{Nm}=$ gene flow. Values presented correspond to an average of all individuals of the species, and are reported with standard deviation $( \pm)$. The analysis was performed for 60 individuals of $P$. raimondii. Total $\mathrm{A}, \mathrm{H}_{\mathrm{t}}$, and $\mathrm{H}_{\mathrm{S}}$ values are reported with standard deviation $( \pm)$. 


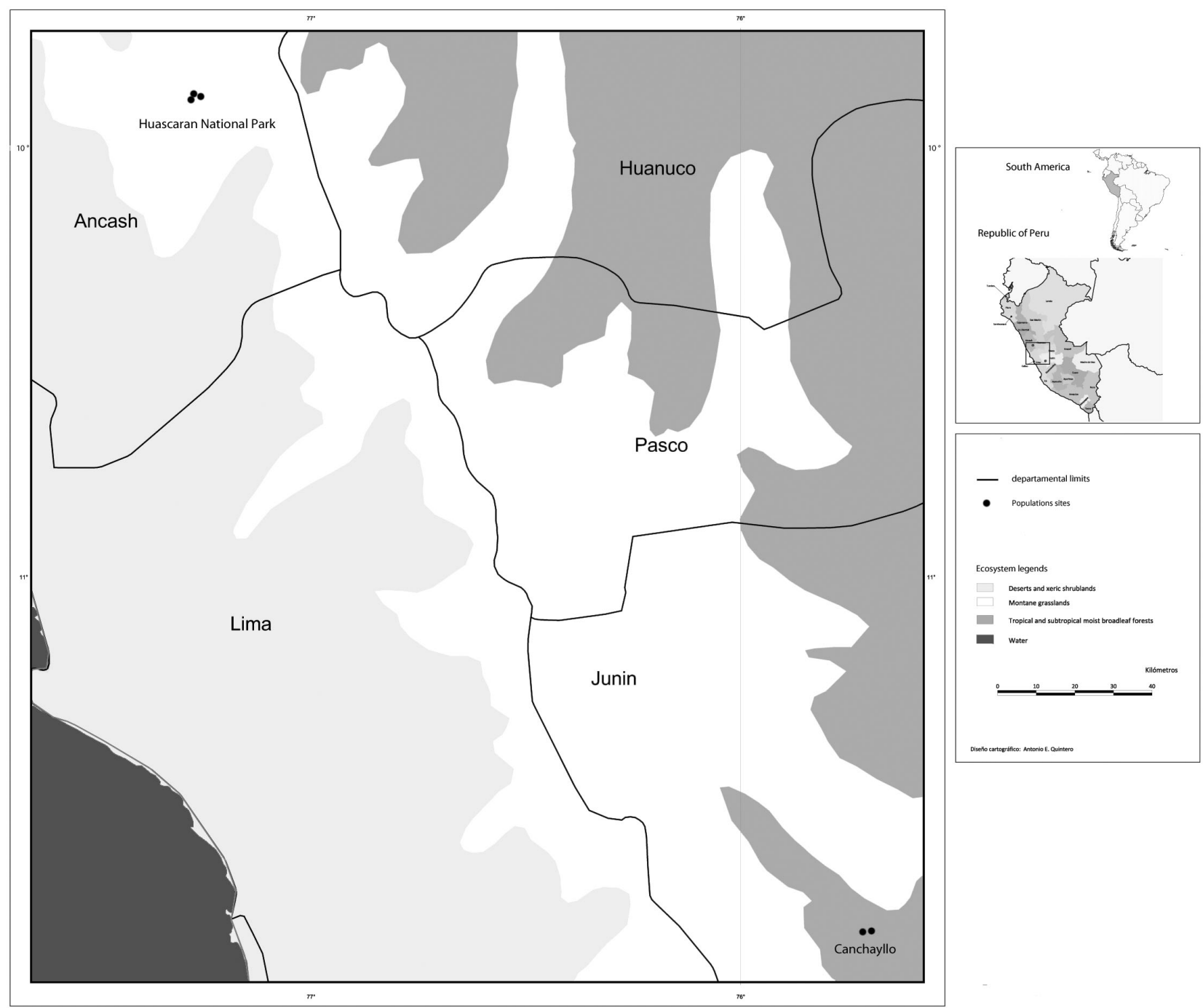

Figure 1. Map of studied populations. Collections were made from five Puya raimondii populations. R1-R3 are from Huascarán, and R4-R5 from Canchayllo, all from Peru. Both localities are separated by $300 \mathrm{~km}$.

\section{AFLP Analysis}

The AFLP protocol reported by Vos et al. (1995) was followed using fluorescently labeled primers. Fragments were separated and observed using a LI-COR automated sequencer (model 4200, LI-COR, Lincoln, Nebraska). For the analysis, four selective AFLP primer combinations were used: EcoRI + AAG/MseI + ACC; EcoRI + ACG/MseI + ACC; EcoRI + AAC/MseI + ACC; EcoRI + AGG/MseI + ACC. Preliminar analysis was performed in laboratory to determine the primers that present variation in few samples. The primers which were selected due to these combinations show clearly a defined band for all samples, and showed variation in this preliminary tests.

\section{Data analyses}

Only unambiguously scorable polymorphic AFLP bands were recorded. For each individual, presence (1) or absence (0) of each band was determined. Distance matrices were calculated using the Dice Index (Nei and Li 1979), and cluster analysis (UPGMA) was carried out using the Freetree program (Hampl et al. 2001). The bootstrap method proposed by Felsenstein (1985) was used to estimate confidence intervals for a group formed at each node by analyzing 1000 bootstrap replicates from the AFLP band data, using the Freetree program (Hampl et al. 2001). Only values over 50 percent were reported. An additional cluster analysis was carried out using the NTSYSpc 2.1 (Rohlf 1998), and the same dendrogram was obtained (data not shown). Also, a principal coordinate analysis (PCoA) was performed using the DICE similarity coefficient and DCENTER, EIGEN and PROJ procedures, with the software NTSYSpc 2.1 (Rohlf 1998). 
Genetic diversity among $\left(\mathrm{H}_{\mathrm{t}}\right)$ and within populations $\left(\mathrm{H}_{\mathrm{s}}\right)$ was estimated; the coefficient of gene differentiation $\left(\mathrm{G}_{\mathrm{st}}\right)$, number of alleles per locus, and gene flow $(\mathrm{Nm})$ were also calculated to summarize data variation observed with dominant markers, such as AFLP. The observed allelic frequency for each population was used to estimate the mean number of alleles per locus (A) and the average proportion of polymorphic loci (P), based on Hardy-Weinberg expectations (Hartl and Clark 1997). All these calculations were conducted with the program Popgene, version 1.32 (Yeh et al. 1997). AMOVA analysis was conducted with Arlequin (Excoffier et al. 2005) for testing population structure and genetic variability among and within populations. The significance test was conducted using 10000 permutations. For population comparisons, 1000 permutations using Fst values were performed; in population differentiation, 10000 Markov steps, with 0.05 significance levels were carried out.

\section{RESULTS AND DISCUSSION}

\section{AFLP polymorphism}

The four primer combinations used in $P$. raimondii generated a total of 172 bands, of which 136 loci, representing $79.1 \%$ of the total, were polymorphic. Populations $1(\mathrm{R} 1)$ and 3 (R3) from Huascarán showed the highest level of polymorphism, with 96 and 130 polymorphic loci, respectively (Table 1). Contrary with the hypothesis based on previous studies, individuals from $P$. raimondii from Huascarán showed higher level of polymorphism than individuals from Canchayllo (Table 1).

\section{Genetic diversity}

Individuals of $P$. raimondii from both Huascarán and Canchayllo populations showed a higher level of genetic variation (Table 1). In Table 2 it is shown that the genetic identity (values above in the diagonal) varies from high values, as 0.935 (R2-R1) and 0.977 (R3-R1), to values below $90 \%$ of identity $(\mathrm{R} 5-\mathrm{R} 1=0.732)$. If the genetic distance is analized (below diagonal), the value is lower in pop R1-R3 (0.024), and individuals from pop R1-R5 which are more distant genetically (0.312), values are greater.
The UPGMA dendrogram based on genetic distances from AFLP (Figure 2) showed two principal branches, with populations mostly grouped according to their geographic distribution. The majority of the individuals in subcluster I correspond to Huascarán, and those in II correspond to Canchayllo. However, populations of $P$. raimondii from Huascarán are mixed (R1, R2, R3) (Figure 2), and so are the populations of this species from Canchayllo (R4, R5). A few individuals from Huascarán appear to be mixed with populations from Canchayllo (e.g. one individual from population R2 with individuals from population R5). Population R5 of P. raimondii collected in Canchayllo showed a high genetic similarity. The PcoA graph shows individuals from different populations mixed (Figure 3). The first principal coordinate described $34.0 \%$ of the total variation. The second principal coordinate described 16.5 $\%$ of the total variation. The two coordinates cumulatively account for $50.5 \%$.

Clusters containing the majority of individuals of P. raimondii from the same geographical location were observed in the UPGMA diagram, suggesting genetic exchange from close populations (e.g. among R4 and R5 from Canchayllo and R1 to R3 from Huascarán). However, individuals from Canchayllo and Huascarán are also found in the same clusters, indicating significant gene flow between the two mountain systems. These results were similar to the PcoA graph, in which individuals from both localities are mixed. Canchayllo and Huascarán are almost $300 \mathrm{~km}$ apart. As a probable cause for the genetic exchange, it is suggested that the winged seeds of this bromeliad are able to disperse over long distances. In plants, a number of models of long-distance seed dispersal have been proposed, and long-distance dispersal is of critical importance to colonization of distant areas (Cain et al. 2000). This has also been noted for the bromeliad Fosterella, for which accidental long-distance dispersal has been suggested in order to colonize distant remote localities in Central America (Rex et al. 2007). Individuals from population R5 showed the minor genetic distance, and it was one of the populations with the fewest individuals in which only a single plant was flowering. Small populations are more susceptible to genetic drift and allele fixation, but gene

Table 2. Nei's genetic distances for Puya raimondii. Values below diagonal refers to genetic distance, and those above, to genetic identity

\begin{tabular}{ccccccc}
\hline Pop. ID & 1 (R1) & 2 (R2) & 3 (R3) & 4 (R4) & 5 (R5) \\
\hline 1 (R1) & -- & 0.935 & 0.977 & 0.799 & 0.732 \\
2 (R2) & 0.067 & -- & 0.945 & 0.877 & 0.835 \\
3 (R3) & 0.024 & 0.056 & -- & 0.787 & -- & 0.734 \\
4 (R4) & 0.225 & 0.131 & 0.239 & 0.160 & -- \\
5 (R5) & 0.312 & 0.180 & 0.309 & & 0.852 \\
\hline
\end{tabular}




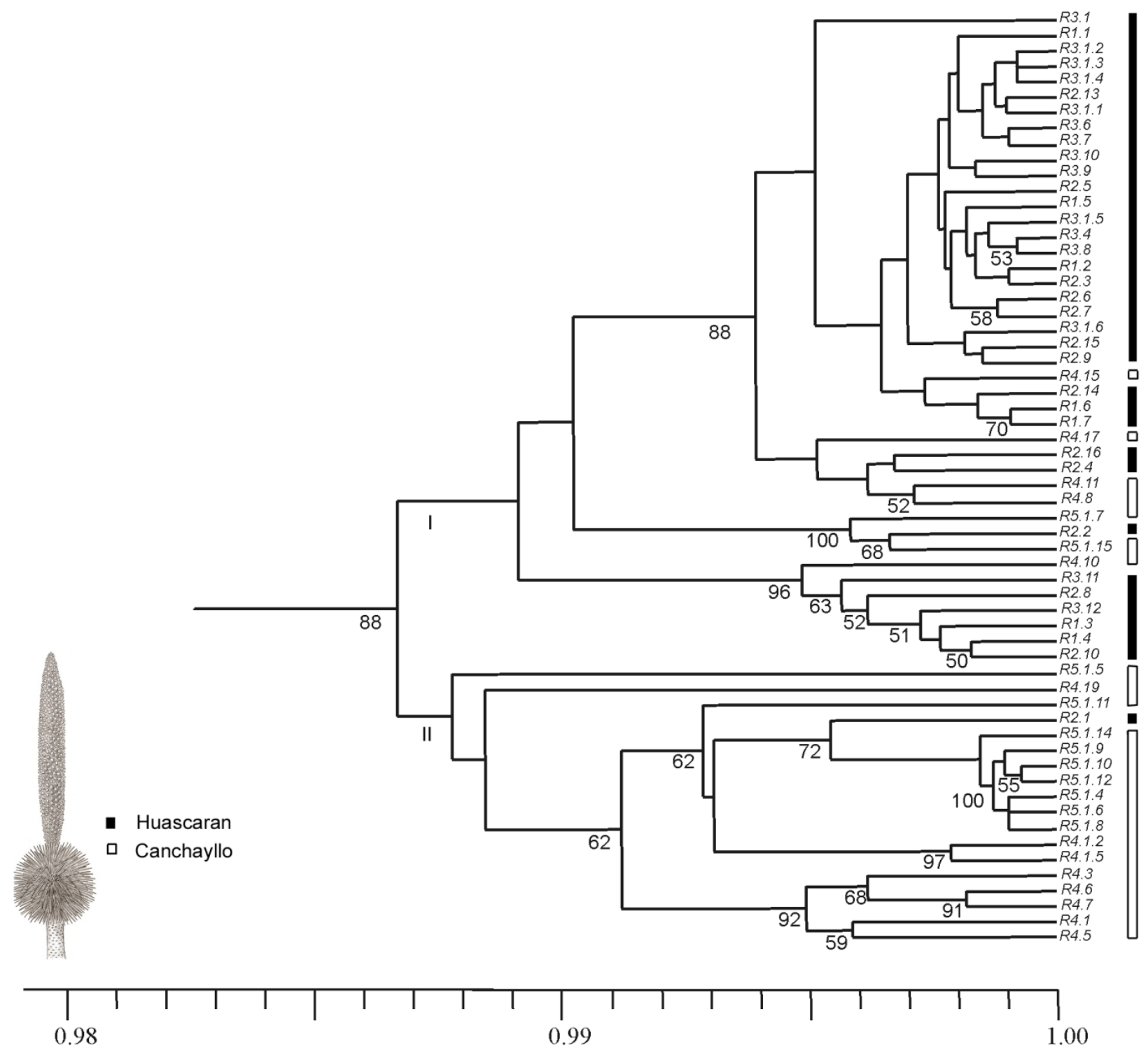

Similarity

Figure 2. UPGMA dendrogram of AFLP markers based on genetic similarity. Individuals of Puya raimondii are represented by " $\mathrm{r}$ " and are followed by individual/population number. Bootstrap values greater than $50 \%$ are indicated. Note that individuals from both mountain systems appear mixed, but the cluster I is mainly composed by individuals from Huascarán, while in cluster II, the majority is composed by Chanchayllo samples.

flow, especially in long-lived species, can prevent genetic differentiation (Loveless and Hamrick 1984).

It has been indicated that monocarpy may reduce flowering population density, limiting mating possibilities (e.g. Tremetsberger et al. 2003). Moreover, the reproductive system determines the way genes are transmitted between generations; levels of genetic variability are consequently closely related to this. P. raimondii showed genetic variation at different levels even though it is a monocarpic species which takes a long time to bloom. $\mathrm{F}_{\mathrm{ST}}$ values showed moderate elevated values (0.32) of differentiation in allelic frequency. This finding was confirmed by the AMOVA analysis (Table 3), which showed significant differences between populations (32.1\%), mainly within populations $(67.9 \%)$. Genetic variation is caused by gene flow between populations as indicated by the values both of Gst and the results of the cluster analysis. The high heterogeneity (Ht) found within populations of this species $(>0.22)$ denotes a high genetic variation. High levels of 
$\operatorname{Dim}-2(16.54 \%)$

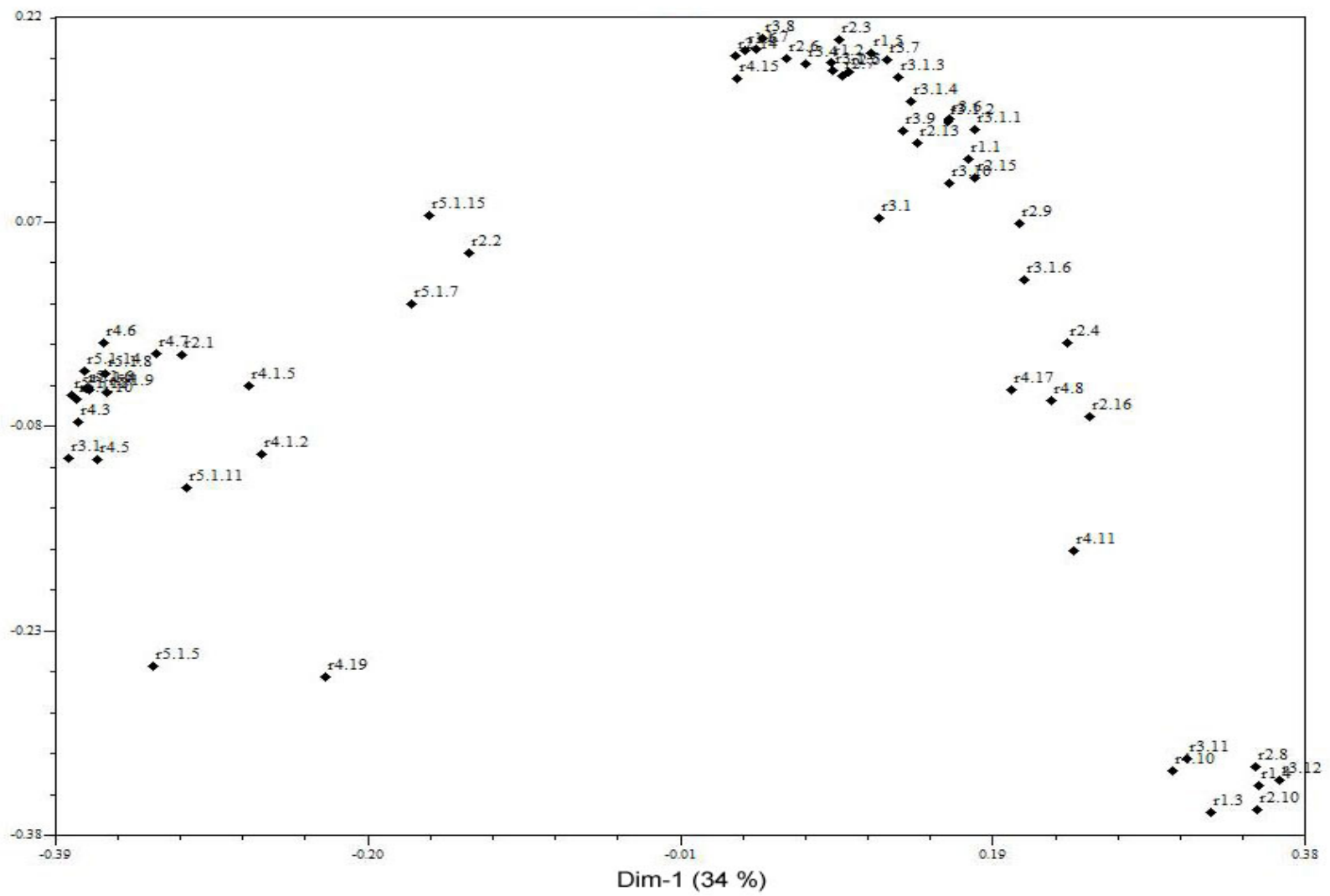

Figure 3. Plot of the individuals of the first two axes of the PCoA. The first axis accounts for $34 \%$ of the variation, and the second axis, for $16.5 \%$.

Table 3. Analysis of molecular variance (AMOVA) partitioning genetic divergence among nine populations of both species of Andean Puya. Significance tested by a permutation analysis against random partitioning of individuals ( 10000 permutations). Genetic differentiation among populations: $\mathrm{F}_{\mathrm{ST}}=0.321$

\begin{tabular}{|c|c|c|c|c|c|}
\hline Source of variation & df & Sum of squares & Variance components & $\%$ of variation & $p$-value \\
\hline Among populations & 4 & 443.704 & 7.330 & 32.1 & $<0.001$ \\
\hline Within populations & 56 & 954.144 & 15.492 & 67.7 & $<0.001$ \\
\hline
\end{tabular}

genetic diversity have been found in other monocots such as Yucca filamentosa, a long-lived, semiwoody, predominantly outcrossing species with a wide geographical range (Massey and Hamrick 1998).

Sgorbati et al. (2004) discovered that populations of $P$. raimondii from Huascarán (Peru) had almost no genetic variation, and reported monomorphic populations showing 98.3\% genetic similarity; they even suggested inbreeding depression. These results contrast with the $96.3 \%$ polymorphism found in the present analysis. Differences between their results and those of this study could be explained in a number of ways: 1) this study may have explored different localities; 2) it compared two different localities separated by barriers: Cordillera Blanca (Huascarán) and Cordillera
Negra (Canchayllo); and 3) it explored different combinations of primers. P. raimondii is distributed in Peru and Bolivia. Further investigation is needed to compare genetic diversity in the entire distribution area of this species.

The results of this study indicate that genetic variation is present in Peruvian populations of $P$. raimondii, the queen of the puna. Molecular markers used in this work revealed a high level of genetic variation; however, $P$. raimondii is subjected to extensive fire and exploitation in the Puna (Sgorbati et al. 2004, Hornung and Sosa 2005). Conservation of rare species must have maintenance of genetic diversity as a high priority (Pullin 2002). Continuous management and monitoring of populations is required to preserve them (Ouédraogo 1996); in situ conservation of $P$. raimondii in Huascarán National Park 
could be an interesting program as a part of global conservation and management of natural biodiversity.

This study provides important information; namely, that in order to promote conservation areas for P. raimondii, genetic exchange of distant individuals must be taken into account. P. raimondi, together with the Andean Bear and the Andean Condor, are emblematic species that need to be conserved.

\section{ACKNOWLEDGMENTS}

The first author thanks the Red Latinoamericana de Botánica for a doctoral scholarship and for special funds to travel to Peru. We are grateful to the Instituto de Recursos
Naturales (INRENA) for authorization to conduct field work and sampling in Peru, and to M. Suni and G. Vadillo for their help at the field. We thank Claudia Moreno, Francis C. Yeh, and Eduardo Ruiz-Sanchez for their help in analysis and use of software. We are also grateful to Emigdia Alfaro, Fernando Hernández, David Espino and Nancy Arias for their support in the laboratory. We thank Margaret Schroeder for reviewing the English version of this paper and to Antonio Quintero for the help with the map. We also thank Dr. Neftali Ochoa Alejo for reviewing the Portuguese version of the abstract. The authors would like to thank the anonymous reviewers for their comments and suggestions to improve the manuscript.

\section{Variação genética na emblemática Puya raimondii (Bromeliaceae) no Parque Nacional Huascarán, no Peru}

Resumo - Puya raimondii, uma bromélia terrestre gigante do Peru e da Bolívia, é uma espécie Andina endêmica e emblemática bem representada no Parque Nacional Huascarán, no Peru. O objetivo deste estudo é caracterizar a variação genética entre e dentro de populações de P. raimondii de Huascarán e áreas vizinhas. Perfis de AFLP com quatro combinações de oligonucleotidios foram recuperados de 60 individuos provenientes de zonas diferentes. A variabilidade genética foi estimada, e um total de 172 bandas foram detectadas, das quais o 79,1\% foram locos polimórficos. Os resultados mostraram a diferenciação genética entre as populações e o fluxo gênico. A análise de cluster mostrou que os individuos de populações de P. raimondii localizados em diferentes sistemas montanhosos agruparam-se, sugerindo dispersão a longa distância. Assim, estratégias de conservação para P. raimondii deve considerar o intercâmbio de indivíduos entre as populações localizadas a longa distância, a fim de preservar a diversidade genética desta espécie.

Palavras-chave: AFLP, populações, fluxo gênico, bromélia.

\section{REFERENCES}

Benzing DH (2000) Bromeliaceae profile of an adaptive radiation. Cambridge University Press, Cambridge, 690p.

Cain ML, Milligan BG and Strand AE (2000) Long-distance seed dispersal in plant populations. American Journal of Botany 87: 1217-1227.

Doyle JJ and Doyle JL (1989) Isolation of plant DNA from fresh tissue. Focus 12: 13-15.

Excoffier, LG Laval and Schneider S (2005) Arlequin ver 3.0: An integrated software package for population genetics data analysis. Evolutionary Bioinformatics Online 1: 47-50.

Felsenstein J (1985) Confidence limits on phylogenies: an approach using the bootstrap. Evolution 39: 783-791.

Hampl V, Pavlicek A and Flerg JJ (2001) Construction and bootstrap analysis of DNA fingerprinting based phylogenetic trees with the freeware program Freetree: application to tricomonad parasites. International Journal of Systematic and Evolutionary Microbiology 51: 731-735.

Hartl DL and Clark AG (1997) Principles of population genetics. Sunderland Mass, Sinauer Associates, 542p.

Hornung-Leoni CT and Sosa V (2004) Uses of the giant bromeliad, Puya raimondii. Journal of Bromeliad Society 54: 3-8.
Hornung-Leoni CT and Sosa V (2005) Morphological variation in Puya (Bromeliaceae): an allometric study. Plant Systematics and Evolution 256: 35-53.

Lambe A (2008) Puya raimondii. In IUCN 2010. IUCN red list of threatened species. Version 2010.1. Available at $<$ www.iucnredlist. org > Acessed on June 11, 2012.

Loveless MD and Hamrick JL (1984) Ecological determinants of genetic structure in plant populations. Annual Review of Ecology and Systematics 15: 65-95.

Massey LK and Hamrick JL (1998) Genetic diversity and population structure of Yucca filamentosa (Agavaceae). American Journal of Botany 85: 340-345.

Murawski DA and Hamrick JL (1990) Local genetic and clonal structure in the tropical terrestrial bromeliad, Aechmea magdalenae. American Journal of Botany 77: 1201-1208.

Nei M and Li WH (1979) Mathematical model for studing genetic variation in terms of restriction endonucleases. Proceedings of National Academy of Science (USA) 76: 5269-5273.

Ouédraogo AS (1996) The role of protected areas in maintaining biodiversity. In Engels JMM (ed.) In situ conservation and sustainable use of plant genetic resources for food and agriculture in developing countries. International Plant Genetic Resources Institute, Rome, p. 94-96 (Report of a DSE/ATSAT/IPGRI workshop). 
CT Hornung-Leoni et al.

Pullin AS (2002) Conservation biology. Cambridge University Press, Cambridge, $345 \mathrm{p}$.

Raimondi A (1874) El Perú. Imprenta del Estado, Lima, 444p.

Ribera M (1992) Regiones ecológicas. In Marconi M (ed.) Conservación de la diversidad biológica en Bolivia. Centro de datos para la Conservación, La Paz, p. 9-71.

Rex M, Patzolt K, Schulte K, Zizka G, Vásquez R, Ibish PL and Weising K (2007) AFLP analysis of genetic relationships in the genus Fosterella L.B. Smith (Pitcairnioideae, Bromeliaceae). Genome 50: 90-115.

Rohlf JF (1998) NTSYSpc. Numerical taxonomy and multivariate analysis system. Version 2.1 Exeter Software, Applied Biostatistics Inc, New York.

Schulte K, Silvestro D, Kiehlmann E, Vesely S, Novoa P and Zizka G (2010) Detection of recent hybridization between sympatric Chilean Puya species (Bromeliaceae) using AFLP markers and reconstruction of complex relationships. Molecular Phylogenetic and Evolution 57: 1105-1119.
Sgorbati S, Labra M, Grugni E, Barcaccia G, Galazo G, Boni U, Mucciarelli M, Citterio S, Benavides A, Venero L and Scannerini S (2004) A survey of genetic diversity and reproductive biology of Puya raimondii (Bromeliaceae), the endangered queen of the Andes. Plant Biology 6: 222-230.

Tremetsberger K, Stuessy TF, Samuel RM, Baeza CM and Fay MF (2003) Genetics of colonization in Hypochaeris tenuifolia (Asteraceae, Lactuceae) on Volcán Lonquimay, Chile. Molecular Ecology 12: 2649-2659.

Vos P, Hogers R, Bleeker M, Reijans M, Van De Lee T, Hornes M, Friters A, Pot J, Paleman J, Kuiper M and Zabeau M (1995) AFLP: a new technique for DNA fingerprinting. Nucleic Acids Research 23: $4407-4414$

Yeh FC, Yang RC and Boyle T (1997) Popgene. CIFOR, v. 1.32, University of Alberta and Center for International Forestry Research, Canada. 